\title{
INTERPRETATION OF THE CAPITOL GROUNDS EXTENSION LAW.
}

\section{(Concluded.)}

III. In so far then as the act authorizes the issuance of warrants or certificates in anticipation of taxes to be collected during a biennial period and to cover any deficiency therein to meet expenses incurred in executing its purposes, not exceeding $\$ 250,000$, it ought not to be denounced as inimical to the provisions of the Constitution quoted. If the last four sections of the act were to be construed as plaintiffs contend these should be, however, a different conclusion would necessarily follow. They say that these authorize the executive council to anticipate the taxes to be levied during the entire ten years amounting in the aggregate to over $\$ 2,200,000, \$ 1,200,000$ of which must be collected after the first biennial period. Were it to be so construed, the limit of $\$ 250,000$ might be exceeded, and unless the principle which governed in Swanson v. City of Ottumwa, 118 Iowa, 161, 91 N. W. 1048, 59 L. R. A. 620 , shall obtain, this would be in violation of section 2 of article 7 of the Constitution. There, the city was authorized to levy a tax annually for a series of years out of which to create a sinking fund for the purpose of the purchase or erection of a system of waterworks, and, in order to meet the present cost, to create a specific fund, by issuing bonds payable only from said sinking fund, from which and the sinking fund on hand to pay the contract price for the erection and completion of said system of waterworks. For the payment of these bonds with interest "shall be pledged the entire proceeds of the two mills sinking fund tax," "and so much of the proceeds of the water rates and rentals collected from consumers and of the water tax *** as shall not be needed for maintenance and operation, repairs and proper and necessary extensions, additions and improvements of said waterworks." The plan was approved by a vote of the electors, a contract entered into, and the city was about to issue bonds such as contemplated, when suit was instituted to enjoin the issuance of the bonds for that, as was claimed, the indebtedness of the city then equalled the constitutional limit and such bonds would create a debt within the meaning of section 3 , art. 11, of the Constitution, declaring that "no county or other political or municipal corporation shall be allowed to become indebted in any manner, or for any purpose, to an amount in the aggregate, exceeding five per 
centum on the value of the taxable property within such county or corporation." On great consideration, the bonds were held not to create a "debt" such as contemplated in the above section; the court, after an exhaustive review of the authorities, saying: "Were we to give the word 'debt' the broad significance that some of the authorities would justify, we should destroy the corporate life and efficiency of every municipality which reached the allowed limit of indebtedness. But the construction we give it has strong support in the decisions of the courts of other states, is in strict line with the opinion we have heretofore frequently expressed, and preserves the integrity of the Constitution according to its evident meaning and intent, while entailing no disastrous consequences to the city or to its citizens. The right of a city to construct and own works of public utility, if such rights exist, is one of great importance, and should not be embarrassed or rendered nugatory by strained or technical construction of the Constitution or of the statutes. Its importance is not so much in the fact that public ownership is in itself wise or desirable (concerning which there may be much difference of opinion) as in the fact that with such power in reserve municipalities are placed in position to deal with private owners on equal terms, and avoid vexations which their helplessness might otherwise invite."

That case is readily distinguishable from that now before us. After the bonds were issued and the system of waterworks purchased or erected, the municipality would have no escape from the levy and collection of the taxes stipulated and the application thereof to the satisfaction of the bonds and interest. In this case, however, the action of one General Assembly is not binding on its successor unless so declared in the fundamental law, and, though the ThirtyFifth General Assembly did enact these statutes relating to the extension of the state capitol grounds, the succeeding General Assemblies are in no manner inhibited from repealing them. Indeed, it will be within the power of the next General Assembly, or any of its successors, if so disposed, not only to repeal chapter 14 of the acts of the Thirty-Fifth General Assembly in its entirety but to dispose of the property acquired thereunder. It is said that the holders of the certificates or warrants take that risk, as these are payable only from the taxes provided in the act. But this is so with every state debt. Though the debt created may constitute a legal obligation, no remedy exists for its enforcement, unless possibly held by another state except as the state may permit, and necessarily the holder must rely upon payment at the option of the state from the only resource available, i. e., taxation. State v. Young, 20 Minn. 474, 9 N. W. 737. Being nonenforceable, such a debt is akin to a moral obligation, and, though condemned as in violation of good morals and as against sound public policy, no one has ever 
questioned the power of a state to repudiate its debts. A subsequent Legislature might repeal chapter 14, and this would leave the certificate without a fund from which to be paid; but it is scarcely conceivable that, after having received the proceeds of the certificates and made use of its own purposes the state would deem the denial of any obligation to repay as consistent with the honor and integrity of a great people. Moreover, section 5 of article 7 of the Constitution prescribes how a debt exceeding $\$ 250,000$ shall be created and paid: (1) For some single work or object; (2) to be paid with interest from an annual tax within 20 years; and (3) applied only thereon. The particular method of creating a fund out of which the state debt, authorized by a vote of the people, shall be paid, is precisely like that contemplated in this act and approved in the Swanson Case. The only possible distinction between the statutory method of providing for the payment of municipal bonds and the constitutional method of providing for the payment of a state debt, voted by a majority of the people, is that, under the former, the bonds are expressly made payable from the sinking fund created by the levy and collection of the taxes authorized only while under the latter the limitation of payment therefrom only is plainly to be implied. The Constitution having particularly prescribed the manner of raising a revenue out of which a debt of the state shall be satisfied, an obligation for an object such as defined in the Constitution and to be discharged as therein directed ought not to be denominated as other than a debt of the state.

Nor do we find the weight of authority otherwise. Section 10 of article 7 of the Constitution of New York, though differing some, is in substance like section 2 of article 7 , and is in words following: "The state may, to meet casual deficits or failures in revenues, or for expenses not provided for, contract debts, but such debts, direct and contingent, singly or in the aggregate, shall not at any time, exceed one million of dollars; and the money arising from the loans creating such debts, shall be applied to the purpose for which they were obtained, or to repay the debt so contracted, and to no other purpose whatever." Section 12, art. 7, Const. 1846 (section 4, art. 7, Const. 1894) is, in all essential particulars, like section 5 of our article 7, and the Court of Appeals, in Newell v. People, 7 N. Y. 11, declared an act authorizing the creation of a fund by the sale of canal revenue certificates for the enlargement and completion of the Erie, Genesee Valley, and Black River Canals and the payment of these from revenue to be derived from taxation during 21 years void as creating a debt in excess of the limitation contained in the section quoted.

Article 12 of the Constitution of North Dakota declares that "the state may, to meet casual deficits, or failure in revenue, or in case of extraordinary emergencies, contract debts but such debts shall never in the aggregate exceed the sum of two hundred thousand 
dollars," with provisions like those contained in sections 4 and 5 of article 7 of our Constitution following. In State v. McMillan, 12 N. D. 280,96 N. W. 310 , the Supreme Court of that state, speaking through Young, C. J., declared an act of the Legislature authorizing the issuance of bonds for the construction of school buildings and payable in the future out of funds derived from the sale of lands set apart for the schools of a state debt and, as that outstanding equalled the limit fixed by the Constitution, the act was held to be in violation thereof; the court following Newell v. People, supra.

Section 5 of article 9 of the Constitution of Minnesota reads: "For the purpose of defraying ordinary expenditures, the state may contract public debts, but such debts shall never, in the aggregate, exceed $\$ 250,000$; every such debt shall be authorized by law, for some single object, to be distinctly specified therein; and no such law shall take effect until it shall have been passed by the vote of two thirds of the members of each branch of the Legislature, to be recorded by yeas and nays on the journals of each house respectively; and every such law shall levy a tax annually sufficient to pay the annual interest of such debt, and also a tax sufficient to pay the principal of such debt within ten years from the final passage of such law, and shall specially appropriate the proceeds of such taxes to the payment of such principal and interest; and such appropriation and taxes shall not be repealed, postponed or diminished, until the principal and interest of such debt shall have been wholly paid." In Brown v. Ringdal, 109 Minn. 6, 122 N. W. 469, the Supreme Court of that state upheld an act authorizing the issuance of interest-bearing certificates of indebtedness, as funds were needed for the construction of a new state prison costing $\$ 2,250,000$, said certificates to be payable out of a fund produced by the levy and collection of taxes amounting to $\$ 225,000$ per year, following Flecten v. Lamberton, 69 Minn. 187, 72 N. W. 65, the court saying: "Counsel for plaintiff differentiates the Lamberton Case by the fact that no certificates of indebtedness were there authorized to be issued, and earnestly insists that this feature of the act under consideration renders it wholly void. We are unable to concur in this claim. The certificates in and of themselves create no indebtedness against the state. On the contrary, they are mere evidence of the holder's right to demand and receive 'from the State Treasurer the proceeds of the tax authorized by the act to be levied and collected, and known and classified as the "Prison Building Fund." Fairly construed, the act contemplates their payment from this fund exclusively, and they are not general obligations of the state. Whatever indebtedness, if any, was created by this act, is, within the Lamberton Case, found in the provisions thereof appropriating $\$ 2,250,000$ for the construction of the new prison and the levy of a tax extending over a period of nine years to produce the same, and not by the issuance of certificates indebtedness evidencing the 
right of the holders thereof to the fund when collected. If the certificates could be construed as creating. an indebtedness against the state payable from the general revenue fund, a different question would be presented. But they are not. They are to be issued in anticipation of funds provided for and appropriated, rightfully under the Lamberton Case, and are valid only as respects that fund when paid into the state treasury."

The majority intimate that but for the prior decision a different conclusion might be reached, but the act considered in the former case merely appropriated any surplus thereafter in the state treasury and the proceeds of an annual levy of two-tenths of a mill upon the assessed valuation of the state for not exceeding ten years to the purchase of a site and the erection of a capitol building at a cost of not exceeding $\$ 2,000,000$. It in no manner contemplated the creation of a debt nor authorized the revenues to be anticipated by the issuance of evidence of debt. It might have been repealed by any subsequent Legislature, but, of course, was the law of the state until repealed in authorizing the levy and collection of this like other taxes. This was pointed out by Lewis, J., in his dissenting opinion in the Brown Case, adding: "The majority hold that the Legislature may provide for the present capitalization of such future conditions by issuing certificates of indebtedness to draw interest to be sold to the public upon the assurance that the credit of the state is behind them, and that the money will be forthcoming when the certificates mature. By this arrangement the entire amount of the tax levy is anticipated, and the amount is available for present purposes. Thus the evidence of a present indebtedness is furnished which may be received with confidence in the commercial world."

The opinion in Flecten $v$. Lamberton, supra, does not disclose that the point now being considered was involved, and as the court in Brown v. Ringdal, supra, gave the question scant, if any, consideration, the latter decision is not persuasive authority. Moreover, in that state a debt in excess of the limit may be authorized by a two-thirds vote of the members of each House of the General Assembly, and whether the act for the construction of the prison was so passed does not appear.

California adopted a Constitution in 1849, article 7 of which provided that the "Legislature shall not in any manner create any debt or debts, liability or liabilities, which shall singly, or in the aggregate, with any previous debts or liabilities exceed the sum of three hundred thousand dollars." Then follows an exception in case of war, invasion, or insurrection, similar to section 4 of article 7 of our Constitution, and provisions for the creation of a debt exceeding that amount like section 5 of that article. In People v. Pacheco, 27 Cal. 175, the Supreme Court of that state, speaking 
through Sawyer, J., held 'an act of the Legislature, in substance' agreeing to pay the interest on $\$ 1,500,000$ of bonds issued by the Central Pacific Railway Company for a period of 20 years and directing that an annual tax of 8 cents on the $\$ 1,000$ taxable property of the state for that purpose, any deficiency to be paid from the general fund on hand and in consideration thereof, the company undertook to carry public messages, lunatics and convicts to and from asylums and prisons, materials for the construction of the state capitol, and munitions of war without other compensation. The preamble indicated it was a war measure and the court upheld it as such. But it also declared that, though the state was indebted beyond the constitutional limit, the act did create a "debt" within the meaning of the article a part of which we have quoted. In doing so, the court, after full consideration, concludes: "Here is a provision for raising a fund and setting apart and appropriating it to the payment of the interest on the bonds-in question, more specific than those in the cases of State v. McCauley, 15 Cal. 429, McCauley v. Brooks, 16 Cal. 24, and Koppikus v. State Capitol Commissioners, $16 \mathrm{Cal}$. 249 , because in those cases the payment was to be made, generally, out of 'moneys in the treasury not otherwise appropriated,' without providing any specific fund and devoting it to that use alone, or knowing whether or not there would in fact be any unappropriated moneys in the treasury at the time payments would fall due. In this case, a specific fund is provided and set apart, to be devoted to the payment of the interest in question alone; and it would seem to be more than ample for the purpose, as the tax provided for on a sum much less than the present assessed valuation of the taxable property in the state, would produce the required amount, and the appropriation from the general fund will not be required until the specific fund is exhausted, which may, and in all probability never will, occur. For these reasons there would be even less propriety in holding this appropriation to be a debt or liability, within the meaning of the constitutional restriction, than those which were the subjects of discussion in the cases cited. The Legislature has provided a fund, and made an appropriation for the entire amount. No further legislation is required upon the subject. Nothing further remains to be done on the part of the state, but the ministerial duty of collecting taxes and paying the interest out of the proceeds, as it from year to year accrues. Of course the state cannot, without a breach of good faith, refuse through its officers to perform this ministerial duty."

An examination of the earlier cases relied upon discloses that, while the contracts entered into extended beyond the time for which taxes were available, no liability was created in excess of which would be in the treasury to meet it. No attention was given the thought that the scheme was like that provided in the article for the creation of an indebtedness in excess of the amount limited. 
The court appears to have relied largely on State v. Medberry, 7 Ohio St. 526 ; but there the decision was that the state might anticipate the revenues to be collected within the biennial period for which the General Assembly may authorize the levy and collection of taxes, and, as a clause in the Constitution forbade appropriations for more than two years, the act authorizing a contract extending over a period of five years was denounced as invalid.

For the reasons already stated, we are not inclined to follow the California decisions. To do so would defeat the manifest design of the people in adopting the section of the Constitution in limiting indebtedness the General Assembly may create. The salutary purpose was to prevent mortgaging the revenues of the state in the future, beyond a specified amount, and, if this is to be rendered, it is quite as essential to denounce a scheme to incur a debt for the payment of which provision is made by a scheme of taxation as a debt to the payment of which no thought has been given. In either event, the funds to meet the obligation must be raised by taxation, and, in either, it is certain to be paid.

The decision in Swanson v. City of Ottumwa, supra, then is not controlling, and, were the act to be construed as authorizing the issuance of certificates payable from taxes levied beyond the biennial period exceeding $\$ 250,000$, it would have to be denounced as inimical to section 2 of article 7 of the Constitution.

IV. The last four sections of the act then are valid, if they may be construed as authorizing the issuance of certificates in anticipation of taxes to be levied and collected in the biennial period during the period of such issue and for any deficiency beyond that to meet the expenses incurred in pursuance of the first eight sections not exceeding $\$ 250,000$. If, however, the act must be construed as conferring authority to issue certificates to cover such deficiency in excess of such amount, the last four sections must be denounced to be inimicable to the fundamental law. The test, as contended by plaintiffs, is not what has been or may be done under the act, but what is authorized to be done in pursuance thereof. As said in City of Beatrice v. Wright, 72 Neb. 689, 101 N. W. 1039: "The vital point to be determined is: What is authorized to be done? The constitutional validity of the law is to be tested, not by what possibly has been or may be done under it," but what can "be done under and by virtue of its provisions," and in the light of the Constitution. The members of the General Assembly which enacts and the Governor who approves, a statute have sworn quite as solemnly to support the Constitution as the members of this court and are to be assumed to have intended to conform their conduct with such obligation. If then two constructions are open and possible without doing violence to the language of the act, one upholding the act as not in violation of the Constitution and the other denouncing 
it as inconsistent therewith, the courts should assume that the lawmakers intended the former and so construe the language thereof as to render it harmonious with the fundamental law. This is in accord with the rule that only when clearly and palpably in violation of some provision of the Constitution will a statute be denounced as inimicable thereto.

In McCullough v. Virginia, 172 U. S. 122, 19 Sup. Ct. 138, 43 L. Ed. 382 , the principle is well stated: "It is elementary law that every statute is to be read in the light of the Constitution. However broad and general its language, it cannot be interpreted as extending beyond those matters which it was within the constitutional power of the Legislature to reach. It is the same rule which obtains in the interpretation of any private contract between individuals. That, whatever may be its words, it is always to be considered in the light of the statute, of the law then in force, of the circumstances and conditions of the parties. So, although general language was introduced into the statute of 1871 , it is not to be read as reaching to matters in respect to which the Legislature had no constitutional power, but only as to those matters within its control and if there were, as it seems there were, certain special taxes and dues which under the existing provisions of the state Constitution could not be affected by legislative action, the statute is to be read as though it in terms excluded them from its operation."

Again, in Chesapeake \& Ohio Ry. Co. v. Kentucky, 179 U. S. 388, 394, 21 Sup. Ct. 103, 45 L. Ed. 244: "Indeed, we are by no means satisfied that the Court of Appeals did not give the correct construction to this statute in limiting its operations to domestic commerce. It is scarcely courteous to impute to a Legislature the enactment of a law which it knew to be unconstitutional, and if it were settled that a separate coach law was unconstitutional, as applied to interstate commerce, the law applying on its face to all passengers should be limited to such as the Legislature were competent to deal with. The Court of Appeals has found such to be the in. tention of the General Assembly in this case, or, at least, that if such were not its intention, the law may be supported as applying alone to domestic commerce. In thus holding the act to be severable, it is laying down a principle of construction from which there is no appeal."

Reverting to the terms of the act, it will be noted that, from the capitol grounds and extension fund, 'the executive council may purchase the lands included in the plat "from time to time, within said period" (section 2) "on option or contracts or any other way which said council may deem expedient * * * at any time within said period of ten years" (section 4). When the several tracts are to be acquired for the state is entirely within the discretion of the executive council. "For the purpose of accom- 
plishing the earliest possible completion of the work contemplated herein and the carrying out the plan provided for in this act, the executive council may anticipate the collection of the taxes here authorized, *** may issue interest-bearing . warrants or certificates" payable from the contemplated fund "each running not more than ten years." Section 9 . The executive council may but is not bound to complete the work at the earliest moment. It may but is not bound to issue certificates. If it so elects, the entire ten years may be taken within which to acquire the land. Even if it should elect to purchase all of that included in the plat, not owned by the state, immediately the evidence is without dispute, that this can be accomplished from the funds available from the taxes to be levied and collected for the years 1913 and 1914 together with the proceeds of certificates not exceeding $\$ 250,000$ in amount. Surely then the act ought not to be construed as authorizing the creation of a "debt" in excess of the limitation contained in section 2 of article 7 of the Constitution. Even if this would not suffice, it is not to be assumed that the executive council would issue certificates exceeding such limit. Every act of the General Assembly is to be read in the light of the Constitution, and the limitations contained therein are as effective as though written into the legislative act. The judiciary is not the only department of government upon which the duty of observing and obeying the provisions of the Constitution devolves. Each of the other departments, legislative and executive, are under precisely the same obligation to know these and obey, and it ought not to be said that such obligation rests more lightly on the one than on the other. All are representatives of the people with different functions to perform, and though the courts are by the Constitution itself made the final arbitrators, in construing its terms and interpreting its meaning, it is never to be lost sight of that, until the contrary appears beyond reasonable doubt, the courts will proceed on the theory that the legislative and executive departments have obeyed its commands and will yield to its injunctions. With the wisdom or expediency of legislation, the courts as such have no concern. Their duty is to construe, apply, and interpret the law, not to enact it, and in so doing we conclude that, when construed in connection with the provisions of the Constitution, the act under consideration cannot be said to authorize the executive council to violate any of its provisions, and, in our opinion, the district court erred in construing any portion of the act as unconstitutional.

Reversed. All the Judges concur. 
Copyright of Annals of Iowa is the property of State of Iowa, by \& through the State Historical Society of Iowa and its content may not be copied or emailed to multiple sites or posted to a listserv without the copyright holder's express written permission. However, users may print, download, or email articles for individual use. 